Research Article

\title{
Linking Meteorological Parameters and Population Dynamics of Jassid (Amrasca biguttula biguttula) in Cotton
}

\author{
Umair Faheem $^{1 *}$, Qaisar Abbas ${ }^{1}$, Saghir Ahmad ${ }^{2}$, Ghayour Ahmad ${ }^{2}$, Abdul Karim ${ }^{2}$ and Mussurat Hussain ${ }^{1}$ \\ ${ }^{1}$ Entomological Research, Sub Station Multan, Pakistan; ${ }^{2}$ Cotton Research Institute, Multan, Pakistan.
}

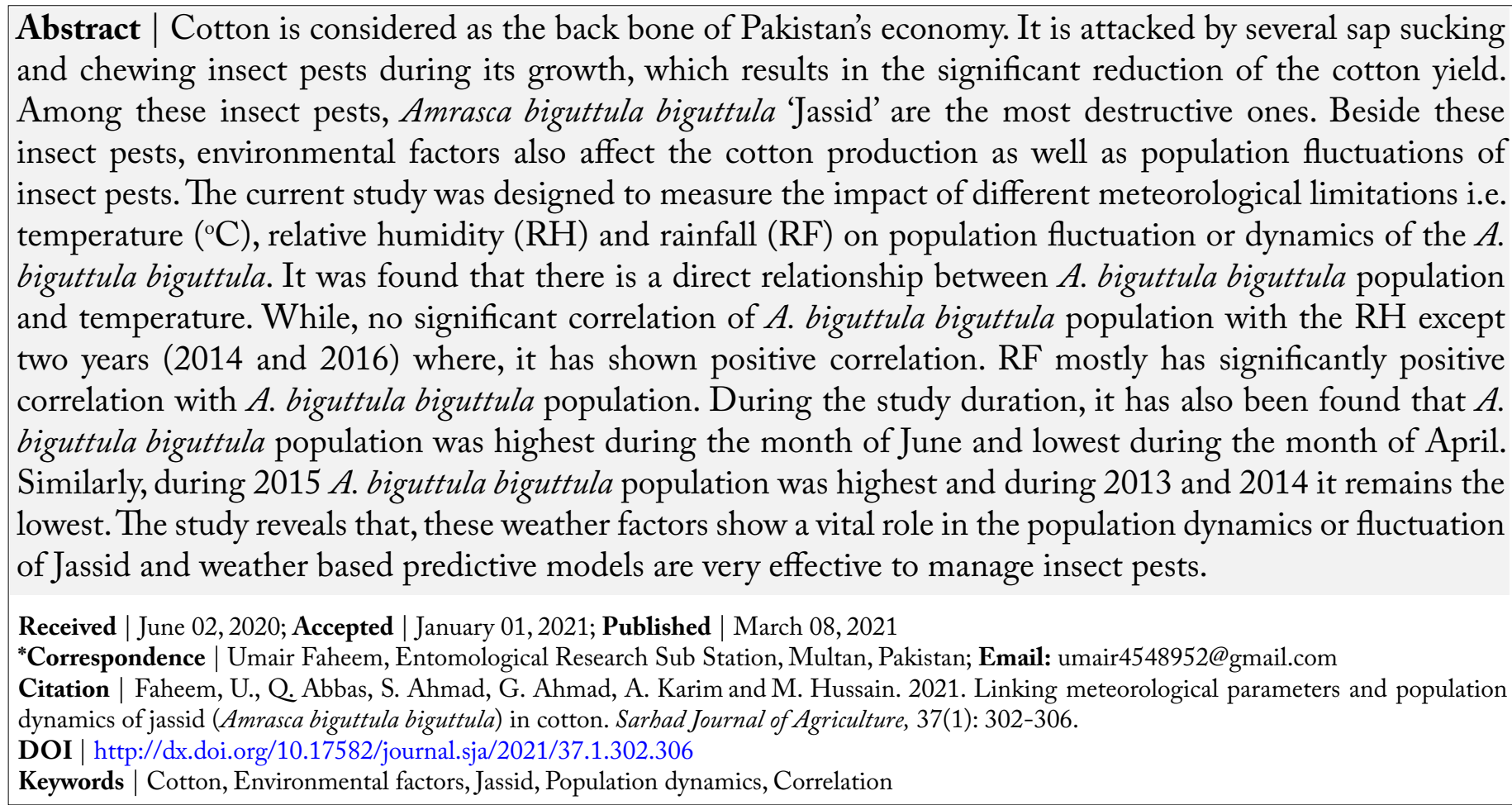

\section{Introduction}

$\mathrm{I}^{\mathrm{n}}$ n Pakistan, Cotton (Gossipium birsutum) is considered as one of the most essential cash crop which plays a crucial role in the country's economy. It is designated as silver fiber and backbone of country's economy (Tayyib et al., 2005). It contributes $5.2 \%$ to the value addition in agriculture and in $1.0 \%$ of gross domestic product (Anonymous, 2016).

There were about 148 insect pest species have been recorded during the growth period of cotton crop, among these only 17 species have been found as major insect pests (Abbas, 2001).
Among these major insect pests, Jassid (Amrasca biguttula biguttula) is considered as one of the most significant insect pests of the cotton. It has been observed that the immatures and adults of $A$. biguttula biguttula suck the cell sap (usually from the underside of the leaves) and during sucking they inject noxious saliva into the plant tissues, which in turn affect leaves into yellowing and curly (Singh et al., 2008).

Environmental factors or parameters play a pivotal role in the cotton production. These factors also affect the life cycle, outbreaks and spread of insect pests at a great magnitude that either force them to acclimatize themselves to these varying climatic factors or escape 
(Pedigo, 2004). The main cause on insect activity is environmental temperature. Prolonged phases of low or high temperatures and unexpected changes in them badly disturb the insect growth. Similarly, altered levels of rainfall (RF) and relative humidity $(\mathrm{RH})$ also fluctuate the population of certain insect pest species (Prasad and Logiswan, 1997).

Knowledge about the abundance and distribution of insect pests in relative to meteorological parameters is the basic requisite for developing pest management strategy for a particular agro ecosystem. Abiotic factors, influence on insect pest abundance and distribution it is therefore, meteorological parameters or factors produce a fundamental role in the biology of any insect pest (Mathur et al., 2012). Abiotic factors and insect pest activity interaction helps in deriving a predictive model that helps in forecast of pest incidence.

This study was designed to measure the role or impact of environmental factors or parameters i.e. temperature, $\mathrm{RH}$ and rainfall on the population dynamics of $A$. biguttula biguttula.

\section{Materials and Methods}

This study was spanned over the period of seven years (year 2011 to 2017) at Experimental Farm Fields (thirty acre) of Cotton Research Institute, Multan, Punjab, Pakistan.

\section{Jassid sampling}

Jassid (Amrasca biguttula biguttula) population was counted from upper, middle and bottom leaves \{ninety (90) leaves\} from thirty (30) randomly selected plants of experimental farm Field, on weekly basis from April to October at $8 \mathrm{am}$ to $11 \mathrm{am}$ and mean population was calculated (Hussain et al., 2014). Different varieties were present in the experimental farm during the studied duration.

\section{Meteorological data}

Seven year (2011 to 2017) meteorological data [maximum temperature (max. temp.), minimum temperature (min. temp.), \%relative humidity (RH) and rainfall $(\mathrm{RF})]$ was obtained from meteorological section of Cotton Research Institute, Multan.

\section{Statistical analysis}

The data was analyzed using statistical software
Statistix 8.1. The means were compared by using Least Significant Difference (LSD) test $(P \leq 0.05)$. The impact of environmental parameters or factors on the adult / nymph population densities of $A$. biguttula biguttula was elaborated by working out simple correlation (Steel et al., 1990).

\section{Results and Discussion}

\section{Impact of environmental factors on Amrasca biguttula biguttula}

Impact of temperature: Table 1 showed that $A$. biguttula biguttula population has significantly $(P \leq 0.05)$ positive correlation with maximum (max.) and minimum (min.) temperature during most of the studied years. Studies of Bishnoi et al. (1996), Men et al. (1996), Umar et al. (2003), Yadav et al. (2009), Harpreet et al. (2015), Aarwe et al. (2016) and Majeed et al. (2016) had also informed the significantly $(P \leq 0.05)$ positive correlation of temperature with the A. biguttula biguttula population. Patel et al. (1997) has opposite results to our study, who informed a negative correlation between population of $A$. biguttula biguttula and environmental temperature.

Table 1: Correlation coefficient of Amrasca bigutella bigutella population with environmental factors during 2011 to 2017.

\begin{tabular}{lllll} 
Year & \multicolumn{4}{c}{ Environmental factors } \\
& Max. temp. & Min. temp. & Relative humidity & Rainfall \\
2011 & $-0.12^{\text {ns }}$ & $0.08^{\text {ns }}$ & $0.21^{\text {ns }}$ & $-0.19^{\text {ns }}$ \\
2012 & $0.63^{*}$ & $0.62^{*}$ & $-0.37^{\text {ns }}$ & $-0.10^{\text {ns }}$ \\
2013 & $0.64^{*}$ & $0.79^{*}$ & $0.02^{\text {ns }}$ & $0.59^{*}$ \\
2014 & $0.78^{*}$ & $0.83^{*}$ & $-0.56^{*}$ & $0.58^{*}$ \\
2015 & $0.23^{\text {ns }}$ & $0.72^{*}$ & $0.20^{\text {ns }}$ & $0.14^{\text {ns }}$ \\
2016 & $0.70^{*}$ & $0.60^{*}$ & $-0.68^{*}$ & $-0.18^{\text {ns }}$ \\
2017 & $0.26^{\text {ns }}$ & $0.48^{\text {ns }}$ & $-0.08^{\text {ns }}$ & $0.76^{*}$
\end{tabular}

Values are mean of $x$ values, Least Significant Difference (LSD) test $(P \leq 0.05)$. "Significant, ${ }^{n s}$ : non-significant.

Impact of relative humidity: While, A. biguttula biguttula population has mostly shown non-significant $(P \geq 0.05)$ correlation with relative humidity $(\mathrm{RH})$ but in 2014 and 2016 it has shown significantly $(P \leq 0.05)$ negative correlation. Wahla et al. (1996) and Harpreet et al. (2015) also testified that the RH is negatively correlated with $A$. biguttula biguttula population. Gogoi et al. (2000) established that the RH promotes the $A$. biguttula biguttula population. 
Table 2: Month and year wise comparison of Amrasca bigutella bigutella population (mean \pm SE) during the year 2011 to 2017.

$\begin{array}{lllllllll}\text { Year } & \text { Months } & & & & & \\ & \text { April } & \text { May } & \text { June } & \text { July } & \text { August } & \text { September } & \text { October } & \text { Mean } \\ 2011 & 0.40 \pm 0.01 & 0.00 \pm 0.03 & 0.74 \pm 0.02 & 0.72 \pm 0.01 & 0.63 \pm 0.02 & 0.74 \pm 0.02 & 0.83 \pm 0.02 & 1.26 \mathrm{c} \\ 2012 & 0.59 \pm 0.00 & 1.14 \pm 0.02 & 1.03 \pm 0.03 & 1.14 \pm 0.01 & 2.13 \pm 0.03 & 1.04 \pm 0.01 & 1.01 \pm 0.04 & 1.38 \mathrm{~b} \\ 2013 & 2.00 \pm 0.02 & 2.57 \pm 0.01 & 2.43 \pm 0.02 & 1.43 \pm 0.01 & 3.14 \pm 0.01 & 2.22 \pm 0.02 & 2.35 \pm 0.01 & 1.12 \mathrm{e} \\ 2014 & 1.00 \pm 0.01 & 2.56 \pm 0.03 & 1.55 \pm 0.02 & 1.80 \pm 0.01 & 2.03 \pm 0.01 & 1.35 \pm 0.03 & 1.45 \pm 0.01 & 1.09 \mathrm{e} \\ 2015 & 1.47 \pm 0.01 & 0.77 \pm 0.04 & 1.25 \pm 0.02 & 1.22 \pm 0.01 & 4.55 \pm 0.01 & 1.93 \pm 0.02 & 0.88 \pm 0.01 & 2.37 \mathrm{a} \\ 2016 & 1.16 \pm 0.03 & 1.33 \pm 0.01 & 0.74 \pm 0.02 & 0.74 \pm 0.02 & 3.05 \pm 0.01 & 0.96 \pm 0.03 & 0.76 \pm 0.01 & 1.29 \mathrm{c} \\ 2017 & 2.26 \pm 0.03 & 1.32 \pm 0.02 & 0.17 \pm 0.03 & 0.65 \pm 0.02 & 1.09 \pm 0.01 & 0.82 \pm 0.03 & 1.02 \pm 0.00 & 1.18 \mathrm{~d} \\ \text { Mean } & 0.58 \mathrm{~g} & 1.15 \mathrm{e} & 2.30 \mathrm{a} & 1.67 \mathrm{c} & 1.72 \mathrm{~b} & 1.24 \mathrm{~d} & 1.04 \mathrm{f} & 0.032\end{array}$

LSD value $\quad 0.020$

Impact of rainfall: On the other hand, $A$. biguttula biguttula population has significantly $(P \leq 0.05)$ positive correlation with rainfall during 2013, 2014 and 2017. Riaz et al. (1987) and Bashir et al. (2001) has also testified a non significant but positive correlation with A. biguttula biguttula population. But the Yadav et al. (2009) have found negative correlation with rainfall.

\section{Population dynamics of Amrasca biguttula biguttula during different months}

Table 2 reveals that the highest mean population 2.30 per leaf of $A$. biguttula biguttula was observed during June which is significantly $\left(P_{\leq} 0.05\right)$ higher from other recorded months. According to Prasad (2008) the peak incidence of $A$. biguttula biguttula was from midSeptember to November. The observations of Shahid et al., 2012 indicates that the highest population of $A$. biguttula biguttula was witnessed during the month of October. Similarly, min. population 0.58 per leaf was found during April, which was significantly $\left(P_{\leq} 0.05\right)$ lower than the other months.

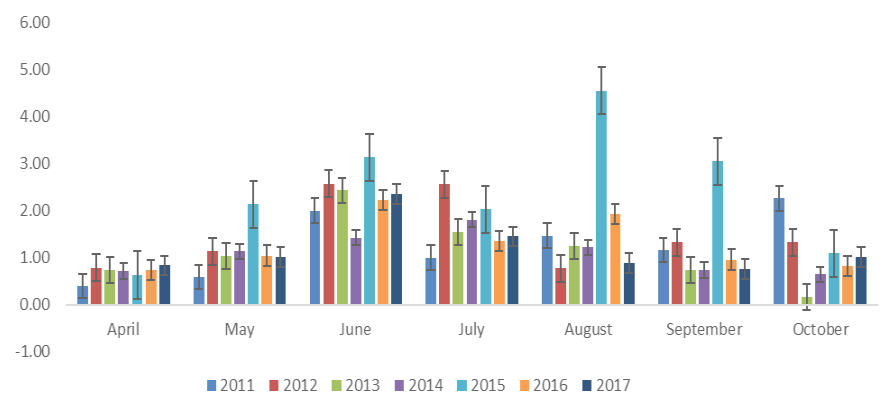

Figure 1: Population dynamics of Amrasca biguttula biguttula in different months during 2011-2017.

Population dynamics of Amrasca biguttula biguttula during different years

On the other hand, highest population 2.37 per leaf of $A$. biguttula biguttula was witnessed during the year 2015 which is significantly $(P \leq 0.05)$ higher as compared to other observed years. While, min. populations 1.09 and 1.12 per leaf were observed during the years 2014 and 2013, respectively. The graphical representation of the population dynamics of $A$. biguttula biguttula has been shown in Figure 1 .

\section{Conclusions and Recommendations}

It can be inferred from the study that the environment has a significant impact on $A$. biguttula biguttula population. A. biguttula biguttula population changes with the change in environmental conditions. $A$. biguttula biguttula population has positive correlation with the temperature and rainfall. Similarly, max. $A$. biguttula biguttula population was observed during the months of June. Insect pest predictive models can be formulated through studies like this to manage insect pests in the field and make spray effective at threshold population.

\section{Novelty Statement}

Research focused on how environmental factors impacts on the population dynamics of Jassid in cotton.

\section{Author's Contribution}

Umair Faheem: Wrote the manuscript.

Qaisar Abbas, Abdul Karim, Ghayour Ahmad and Mussurat Hussain: Collected the data.

Saghir Ahmad: Analysed the data.

\section{Conflict of interest}

The authors have declared no conflict of interest. 


\section{References}

Aarwe, R., R. Pachori, A.K. Sharma, A.S. Thakur and R. Mandloi. 2016. Impact of weather factors on the incidence of major insect pests of okra (Abelmoschus esculentus L. moench). Int. J. Agric. Sci., 8(3): 981-983.

Abbas, M.A., 2001. General agriculture. Publ. Emporium. 2nd (Edn.), Pak. pp. 352.

Anonymous, 2016. Economic survey of Pakistan. Minist. Finance, Govt. Pakistan. pp. 19.

Bashir, M.H., M. Afzal, M.A. Sabriand, A.B.M. Raza. 2001. Relationship between sucking insect pests and physico-morphic plant characters towards resistance/susceptibility in some new genotypes of cotton. Pak. Ent., 23(12): 75-78.

Bishnoi, O.P., M. Singh, V.U.M. Rao, R. Niwasand and P.D. Sharman. 1996. Population dynamics of cotton pests in relation to weather parameters. Indian J. Ent., 58: 103-107.

Gogoi, I., B.C. Dutta and Gogoi. 2000. Seasonal abundance of cotton Jassid on okra. J. Agric. Sci. Soc., North-East India, (13): 22-26.

Harpreet, S., K. Prabhjyot and J. Mukherjee. 2015. Impact of weather parameters and plant spacing on population dynamics of sucking pests of cotton in South Western Punjab. J. Agric. Phys., 15(2): 167-174.

Hussain, M., M. Akram, Q. Abbas, S. Ahmad, T.K. Babar and H. Karar. 2014. Impact of environmental factors on the population dynamics of leaf hopper Amrasca biguttula biguttula ishida (Homoptera: Jassidae) on various transgenic cotton genotypes in Multan. Acad. J. Entomol., 7 (1): 27-31.

Majeed, M.Z., M. Javed, M.A. Riazand and M. Afzal. 2016. Population dynamics of sucking pest complex on some advanced genotypes of cotton under unsprayed conditions. Pak. J. Zool., 48(2): 475-480.

Mathur, A., N.P. Singh, M. Meena and S. Singh. 2012. Seasonal incidence and effect of abiotic factors on population dynamics of major insect pests on brinjal crop. J. Environ. Dev., 7(1): 431-435.

Men, V.B., D.N. Sarniaik, L.N. Peshkar, S.D. Deshmukh, A. Muqueem, M.V. Nachane, M.V. Akhare, H.G. Kanddalekar, R.B. Gawande, H.S. Thakare, S.S. Radhke, G.R. Falzele and R.V. Kolhe., 1996. Effect of weather factors on the population of Jassids. PVK. Res. J., 20(2): 151-154.

Patel, K.I., J.R. Patel, D.B. Jayani, A.M. Shekh and N.C. Patel. 1997. Effect of seasonal weather on incidence and development of major pests of okra (Abelmoschu sesculentus). Indian J. Agric. Sci., pp. 67.

Pedigo, L.P., 2004. Entomology and pest management. Prentice Hall of India, New Delhi. $4^{\text {th }}$ Edition, pp. 175- 210.

Prasad, N.V.V.S.D., N.H.P. Rao and M.S. Mahalakshmi. 2008. Population dynamics of major sucking pestsinfesting cotton and their relation to weather parameters. J. Cotton Res. Dev., 22 (1): 85-90.

Prasad, S.G. and G. Logiswaran. 1997. Influence of weather factors on population fluctuation of insect pest of brinjal at Madurai, Tamilnadu. Indian J. Ent., 59: 385-388.

Riaz, M., M.A. Chaudhry, A. Ali and L. Khan. 1987. Physio-chemical aspects of resistance in cotton to insect pests complex. Sarhad J. Agric., 3(4): 491-497.

Shahid, M.R., J. Farooq, A. Mahmood, F. Ilahi, M. Riaz, A. Shakeel, I. Valentin Petrescu-Mag and A. Farooq. 2012. Seasonal occurrence of sucking insect pest in cotton ecosystem of Punjab, Pakistan. Int. J. Bioflux Soc., 4(1): 2630.

Singh, S., D.P. Choudhary, H.C. Sharma, R.S. Mahla, Y.S. Mathur and D.B. Ahuja. 2008. Effect of insecticidal modules against Jassid and shoot and fruit borer in okra. Indian J. Ent., 70(3): 197-199.

Steel, R.G.D., J.H. Torrie and D.A. Dickey. 1990. Principles and procedures of statistics: A biometrical approach, $3^{\text {rd }}$ edition. WCB MeGraw Hill Companies, Inc., USA.

Tayyib, M., A. Sohail, A. Shazia, Murtaza and F.J. Fatima.2005.Efficiency of some new-chemistry insecticides for controlling the sucking insect pests and mites on cotton. Department of Agri. Entomology, University of Agriculture, Faisalabad, Pakistan. Pak. Ent., 1: 27.

Umar, M.S., M.J. Arif, M.A. Murtaza, M.D. Gogi and M. Salman. 2003. Effect of abiotic factors on the population fluctuation of whitefly, Bemisiatabaci (Genn.) in nectaried and nectariless genotypes of cotton. Int. J. Agric. Biol., 5: 362-368.

Wahla, M.A., J. Arif and M. Afzal. 1996. The 
impact of physical factors on the population dynamics of sucking pest complex of "FH-87" cotton variety. Pak. Ent., 18(2): 566-585.

Yadav, J.B., R.S. Singh, H.P. Singh and A.K. Singh. 2009. Effect of abiotic and biotic factors on Jassid and Fruit and Shoot borer in kharif Okra Crop. Int. J. Plant Prot., 2(1): 119-122. 